\title{
The Reality of Reparations: An Exploration of Neo-Colonialism, Morality and Control in the Caribbean
}

\section{Amna Khan}

King's College London

Religion, Politics \& Society BA

\section{A B S T R A C T}

Reparations are widely understood as the process by which compensation is given or amends made for previous wrongdoing. In the context of the Caribbean, it may refer to official actions taken by former colonial powers to acknowledge and recompense states affected by colonialism and slavery. This paper seeks to analyse discussions of reparations in the region and consider how the lack of compensation may be perceived as demonstrating that modern power relations are merely repackaged propagations of imperialism. Fundamentally, this paper argues that the notion that colonisation was left behind in the 19 th century with the abolition of slavery or mid-20th Century with the political independence of Caribbean nation-states is a facade and uses reparations discourse as the foremost example of such. This is demonstrated through the following questions: Why do reparations need to be paid? Why are they not being paid? And What needs to change?

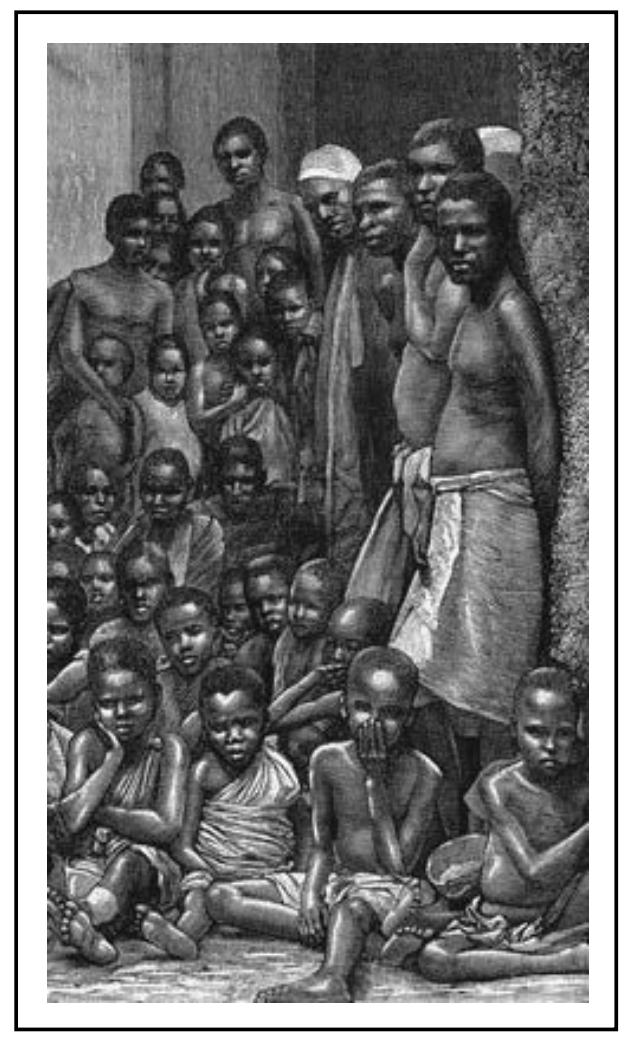

Keywords: Caribbean politics, reparations discourse, colonialism, neo-colonial economics, CARICOM

B I O

Amna Khan is a final year student studying Religion, Politics \& Society at King's College London. She completed this paper as part of her semester abroad with University of Toronto. Her focuses include the intersections of politics and its surrounding themes in current global discourses and the history of capitalism in modern cities. 
The historical events of colonial slavery were undeniably tragic; however, reparations discourse also looks to ending the "continuing dispossession" of the oppressed communities colonial systems created. ${ }^{4}$ The unfortunate reality is that when Caribbean states assumed their independence beginning in the 1960s, the institutional features of their colonial subjection did not immediately disappear. Instead, these same oppressive policies took new forms. Not only was this evident through ${ }^{1}$ Caribbean governments, some of whom are still recovering from lingering ideological rejections of democracy instilled by experiences of corrupt and unrepresentative leadership, but analyses of major American and British infrastructures and corporations reveals that they too were founded on the exploitation of slaves. This highlights the ways in which the continued existence of colonial systems and organizations is a preservation of those colonialist ideologies at the continued determent of the subaltern

British historian David Olusoga generated a database in collaboration with University College London (UCL) entitled 'Legacies of British slave-ownership' which offers an interface through which members of the public can observe the quantifiable foundation from which major British establishments were built on slavery. The commercial database involves over 1400 individuals and information on broader cultural and political legacies. For example, the Bank of England alone has relationships with twenty-nine individuals and investors who had slave-related legacies. ${ }^{5}$ The Bank of England remains the central bank of the United Kingdom. Thus, it is a reminder of the ways in which the subject of reparations stays ever-present in modern discourses where relationships from slavery and colonization are widely identifiable. This is especially applicable when one considers that official monetary acknowledgements have never been in favour of the slaves. Part of the Abolition Act of 1833 Britain compensated 46,000 slave-owners with $£ 20$ million for their "loss of human property;" but neglected to provide any form of apology or recompensation for the real victims. ${ }^{6}$

In 'The Case for Reparations' event held in summer 2020, Hilary Beckles mentioned how the events catalyzed by George Floyd's death in March of that year reaffirmed how the disposal of black lives has been entrenched since colonial days. This is evidence of how the effects of slavery are not simply traceable to historical periods but rather its victims are produced ad infinitum, "long after the active stage of crime has ended"? Further, its lasting destruction affects a multitude of experiences, from economic to ideological and cultural. Strecker's exploration of the 'Ongoing Violations of Indigenous Rights' across the Caribbean evidences how land rights for native communities are

\footnotetext{
4 Amy Strecker, "Indigenous Land Rights and Caribbean Reparations Discourse," Leiden Journal of International Law 30, no. 3 (2017): 633, https://doi.org/10.1017/S0922156517000073

${ }^{5}$ University College London (UCL), "Legacies of British Slave-ownership,” University College London Department of History, accessed April 3, 2021, https://www.ucl.ac.uk/lbs/.

${ }^{6}$ David Olusoga. "The Treasury's tweet shows slavery is still misunderstood," The Guardian, February 12, 2018,

${ }^{7}$ Randall Robinson, The Debt, What America Owes To Blacks (New York: Plume Books, 2000), 216.
} 
both lacking and not effectively implemented. For example, Strecker accuses the Surinamese government of repeatedly failing to protect its N'dujka, Kalina and Lokono communities from mining interventions of their lands. 8

In Belize, where there are some international laws in place for Mayan land rights but these are not fully implemented. Only two of the thirty-eight villages in the Toledo district were actually protected. This reveals that even where acknowledgements are beginning to be made for comparable subaltern communities, they are not always followed through by relevant authorities. Simultaneously, public apologies for the historic significance and existing unacceptability of slavery have begun to be made, as seen by British Prime Minister Tony Blair early on in his tenure. Regardless, the expectation of reparations by the Caribbean nations remains strong. So, why are they not being paid?

The awareness about the inhumanity of slavery has long existed but for as long as these have been present, pro-slavery voices have been giving arguments as for why the process was justified or ultimately a net positive. These are extremely problematic as firstly, they are rooted in dehumanizing economic and legalistic terms - that may be perceived as the result of the commodification of man by the capitalistic nature of the modern world and secondly because these are perspectives consistently perpetuated by the dominating force of the oppressor-oppressed relationship. In my exploration of the reason reparations claims have been largely ignored by the modern western world, I go into detail on these economic and legal bases from which pro-slavery literature has been grounded.

The legality of slavery has been long contested with authorities of European colonial powers consistently denying its criminality on the grounds that "law is district from morals" ". Brophy considers this question in his review of Beckles' magnum opus Britain's Black Debt, writing that Beckles adopts the perspective that what is legal should refer to some "seemingly universal moral standards... outside of the courts and outside of Parliament" and based on a "natural law conception rather than a positive law conception"." 1. However, I recognise that this could be considered an idealistic conceptualisation where philosophically speaking, what one perceives as moral, the other may not. Just because something seems like it should be absolute does not mean it necessarily is, thus this exploration of the definition of 'legal' further obscures the already complex reparations discourse The question of law also applies to modern day treaties as Strecker notes there is a lack of recognised "continuity between colonial administrators and newly independent states" where such is necessary for realistic acknowledgements of

\footnotetext{
8 Strecker, "Indigenous Land Rights," 637.

9 Strecker, "Indigenous Land Rights," 640.

10 Alfred L. Brophy, "The Case for Reparations for Slavery in the Caribbean," Slavery \& Abolition 35, no. 1 (2014): 165, DOI: 10.1080/0144039X.2013.847222.

${ }^{11}$ Brophy, "The Case for Reparations," 168.
} 
previous wrongdoings to be made. Instead, the projected removal of colonisation from present discourses means there need not be acceptance of past tragedies as these institutions no longer exist, technically speaking. However, the reality is nowhere near as clear cut as European history would like us to believe. In the same vein that Olusoga reported the actual end of slavery came thirty years after its focal abolition, reparations discourse is not merely a consideration of past events. ${ }^{12}$ It may be argued, for example, that historically, many of the legal allocations and justifications of slavery were based in the fact that its economic benefits were clearly observable, falling victim to Brophy's prophecy that "morality is so often sacrificed for money"13 American abolitionist Ralph Waldo Emerson contained this perspective through his notion that "slavery and anti-slavery is the question of property and no property" demonstrating how the basis of the slave trade was the exploitative commodification of man to labour the mass consumption of the industrial revolution. ${ }^{14}$

This schema of capital accumulation dictating social philosophy and livelihood is conceptually defined by the Marxist base and superstructure cyclical framework, within which society's means of production have direct influence over its laws, media, culture, politics and so on ${ }^{15}$
At the same time European colonial expansion was gaining tract, capitalism was becoming consolidated as the economic foundation of the modern world. With such, the characteristics of individual profiteering, private accumulation and disenfranchisement of the lesser classes became standard and projected across the colonies of the European empire, fulfilling Lenin's framework of 'imperialism as the latest stage of capitalism'. Here, I map how imperialist ideological and institutional frameworks persist in the present world through framelforks established during this vacuum of industrialisation, capitalisation and colonialism of the 19th and 20th centuries. As evidence for these economic justifications of slavery, I look to Cowen's analysis of how modern Canadian city infrastructures are revelatory of historic 'settler' relations, such as the Canadian Pacific Railway being funded in part from transatlantic slave funds and simultaneously being the current major port access from Canada to North America. ${ }^{16}$ In other words, both the development of these infrastructures themselves and their financing reproduces "nationalistic... material relations" rooted in and thus preserving "violence... (and) colonial dispossession" to this day. ${ }^{17}$

\footnotetext{
${ }^{12}$ Strecker, "Indigenous Land Rights," 635.

13 Olusoga, "The Treasury."

14 Brophy, "The Case for Reparations," 165.

${ }^{15}$ Karl Marx, A Contribution to the Critique of Political Economy, trans. S.W. Ryazanskaya ( Moscow: Progress Publishers, 1859).

${ }^{16}$ Deborah Cowen, "Following the infrastructures of empire: notes on cities, settler colonialism, and method," Urban Geography 41, no. 4 (2020): 469-486, DOI: 10.1080/02723638.2019.1677990.

${ }^{17}$ Cowen, "Following the infrastructures," 469-471.
} 
Cowen's article demonstrates the high extent to which colonialist sentiments are present in modern urbanisation. The historic prioritisation of economic gain over humanistic value was introduced by the commodification of man by slavery and evidentially exists to this day, providing grounds for authorities within the capitalistic worldview to reject reparations discourses.

Considering these perspectives, the question of 'what needs to change?' in order to facilitate an understanding of slavery and repatriations in line with modern morality remains. The reality is that the Black racial experience is continually repressed through structures which are inherently imperialistic. The acknowledgement and apology involved in reparations is necessary for many communities to come to terms with their histories and improve their present livelihoods. As highlighted through his criticism of the second half of Beckles' book, where Beckles discusses how reparations should be paid to descendants of the exploited, Brophy asserts that the "victims of slavery are still alive and well" and thus their acknowledgement is just as pressing. 18

The main avenue through which reparations have been officially presented is CARICOM's Reparations Commission (CRC), which was set up following the 2001 World Conference against
Racism held in Durban. ${ }^{9}$ The CARICOM website states its output "outlines the path to reconciliation, truth, and justice" and this is achieved through their ' 10 Point Plan for Reparatory Justice' published in March 2014 with British law firm Leigh Day. ${ }^{20}$ Some of these include attention to repatriation (point two), illiteracy eradication (point six) and debt cancellation (point nine), which is demonstrative of their multi-faceted consideration. Whilst catalytic for specific acknowledgement policies, CARICOM's establishment focuses on interstate claims where wider reparations discourses must be adopted by international powers in order to be most extensively effective.

Having just explored the economic spotlight of reparations discourses, a major development which needs to be made by the international authorities involved is reparatory justice goes beyond monetisation. As I have explored through this paper, whilst colonialism and slavery were destructive to native economies, they also impacted ideologies, cultural histories, land rights and so on. Not only this but their destruction was not one-dimensional, affecting the intersections of labour and capital which influence modern conceptualisations of value and experiences of livelihood in the capitalistic worldview we exist in.

\footnotetext{
18 Brophy, "The Case for Reparations," 167.

19 Strecker, "Indigenous Land Rights," 632.

20 "CARICOM Ten Point Plan For Reparatory Justice," CARICOM Caribbean Community, accessed March 30, 2021, https://caricom.org/caricom-ten-point-plan-for-reparatory-justice/.
} 
A central form of reparatory justice which I believe is consistently overlooked is that of cultural heritage, supported as Lixinski communicates such objects and histories have "essential symbolic importance... (in) cultural revival and importance"21 This is especially significant where indigenous people are consistently victim to cultural loss and erasure with the "traditional narrative of extinction" constantly pushed by modern capitalistic powers?2 This is a consideration evident in point four of CARICOM's plan about 'Cultural Institutions' which states European museums and research centres have access to "facilities to reinforce the consciousness of citizens in history as rulers and change agents" that Caribbean educators don't. ${ }^{23}$ On the subject of the reparations for cultural heritage, this is directly observable through museum institutions which actively house artefacts stolen from the colonial period. For example, in 2019, together with the National Reparations Commission, Jamaica's Culture Minister Olivia Grange requested artefacts made by the indigenous Taino people "including a 500-year-old carved wooden figure of a rain god" to be returned by the British Museum? 24

Essentially, for reparations discourses to become more effective in their contents and implementation, the redefinition of terms which centralise the human needs to take place in their evolution. In order to make this realistic, this involves European acknowledgement of its colonial history involving reparatory justice beyond distancing itself from the past. This is purported through Strecker's recommendations for these international authorities to actively fulfil their "political and moral obligation" to improve accessibility to physical means of heritage in their position as ex-oppressor with current dominating power. Also, reparations discourse involves affirmative action as much as it does historic acknowledgement in order to be fully effective. This is evident via Ray \& Perry's executive summary published by a non-profit policy research organisation on 'Why We Need Reparations for Black Americans' citing "The Harriet Tubman Community Investment Act" as a good template for reparatory considerations to be structured in its address of "education, homeownership, and business ownership barriers" in practice.

My exploration of reparations and its surrounding discourse proves how it is a consideration which is undeniably historically entrenched and requires far more attention than has been given in the international arena. I observe that the general rejection of claims for reparatory justices made by Caribbean nations to European western powers is evidence for how their current global dominance is based in those previous colonial

21 Strecker, "Indigenous Land Rights," 644.

22 Strecker, "Indigenous Land Rights," 645.

23 CARICOM, "CARICOM Ten Point Plan."

24 Mark Brown, "Jamaica seeks return of artefacts from British Museum," The Guardian, August 7, 2019, https://www.theguardian.com/world/2019/aug/07/minister-seeks-return-of-priceless-artefacts-from-british-museum

25 Strecker, "Indigenous Land Rights," 645.

28 Brophy, "The Case for Reparations," 168.

27 Ray \& Perry, "Why we need reparations," 4. 
conceptualisations of control and trade they so wish to remove themselves from, with the reality being that so many modern establishments and infrastructures preserve the very frameworks that reparations seek to acknowledge. To conclude this research paper, I quote one of Hilary Beckles' final remarks on the topic: "The darkness of slavery will hover overhead until the illumination of reparative discourse takes effect and allows justice to be achieved". 28

28 Hilary Beckles. Britain's Black Debt: Reparations for Caribbean Slavery and Native Genocide (Kingston: University of West Indies Press, 2013), 23. 


\section{Works Cited}

Anti-Slavery. "Tony Blair apologies for Britain's role in the Slave Trade." Accessed July 14, 2021. https://www.antislavery.org/tony-blair-apologies-britains-roleslave-trade- $2 /$.

Baksi, Caroline. "The story of the Zong slave ship: a mass murder masquerading as an insurance claim.” The Guardian, January 19, 2021.

https://www.theguardian.com/law/2021/jan/19/the-story-of-the-zong-slave-ship-a -mass-masquerading-as-an-insurance-claim.

Beckles, Hilary. Britain's Black Debt: Reparations for Caribbean Slavery and Native Genocide. Kingston: University of West Indies Press, 2013.

Brophy, Alfred L.. "The Case for Reparations for Slavery in the Caribbean." Slavery \& Abolition 35, no. 1 (2014): 165-169. DOI: 10.1080/0144039X.2013.847222.

Brown, Mark. "Jamaica seeks return of artefacts from British Museum." The Guardian, August 7, 2019. https://www.theguardian.com/world/2019/aug/07/minister-seeksreturn-of-priceless-artefacts-from-british-museum.

CARICOM. "CARICOM Ten Point Plan For Reparatory Justice.” Accessed March 30, 2021. https://caricom.org/caricom-ten-point-plan-for-reparatory-justice/.

Cowen, Deborah. "Following the infrastructures of empire: notes on cities, settler colonialism, and method.” Urban Geography 41, no. 4 (2020): 469-486. DOI: 10.1080/02723638.2019.1677990.

Knight, Andy \& Beckles, Hilary. "The Case for Reparations.” Bocas Lit Fest video, 8:20. October 12, 2020. https://uwitv.org/intv/the-case-for-reparations-conversation-with -prof-sir-hilary-beckles.

Marx, Karl. A Contribution to the Critique of Political Economy. Translated by S.W. Ryazanskaya. Moscow: Progress Publishers, 1859.

Olusoga, David."The Treasury's tweet shows slavery is still misunderstood." The Guardian, February 12, 2018. https://www.theguardian.com/commentisfree/2018/ feb/12/treasury-tweet-slavery-compensate-slave-owners.

Ransom, Roger. "The Economics of the Civil War.” Accessed April 2, 2021. http://eh.net/encyclopedia/the-economics-of-the-civil-war/.

Ray, Rashawn \& Perry, Andre M. "Why we need reparations for Black Americans." Policy 2020 Brookings. Accessed March 29, 2021. https://www.brookings.edu/policy2020/bigideas/why-we-need-reparations-forblack-americans/.

Robinson, Randall. The Debt, What America Owes To Blacks. New York: Plume Books, 2000.

Strecker, Amy. "Indigenous Land Rights and Caribbean Reparations Discourse." Leiden Journal of International Law 30, no. 3 (2017): 629-646.

University College London (UCL). "Legacies of British Slave-ownership." University College London Department of History. Accessed April 3, 2021. 